DOI https://doi.org/10.30525/978-9934-26-074-2-41

\title{
ПРИЗНАЧЕННЯ СУДОВО-ПСИХІАТРИЧНОЇ ЕКСПЕРТИЗИ В АДМІНІСТРАТИВНОМУ ПРОВАДЖЕННІ
}

\author{
Яремчук М. М. \\ кандидат юридичних наук, \\ методист відділення забезпечення якості освіти \\ відділу забезпечення якості освіти та методичної роботи \\ Львівського державного університету внутрішніх справ \\ м. Львів, Украӥна
}

При розгляді справ про адміністративні правопорушення досить часто виникає необхідність у використанні різноманітних засобів доказування в тому числі залучення до справи осіб, які мають спеціальні знання. Судова експертиза є одним із найважливіших засобів повного та об'єктивного дослідження обставин вчиненого правопорушення, але положення чинного Кодексу України про адміністративні правопорушення (далі КУпАП), які регулюють порядок та підстави проведення експертиз $є$ недосконалими, тому $є$ потреба в розробці пропозицій щодо усунення недоліків.

Відповідно до ст. 20 КУпАП Не підлягає адміністративній відповідальності особа, яка під час вчинення протиправної дії чи бездіяльності була в стані неосудності, тобто не могла усвідомлювати свої дії або керувати ними внаслідок хронічної душевної хвороби, тимчасового розладу душевної діяльності, слабоумства чи іншого хворобливого стану[1].

У Верховній Раді України зареєстровано законопроєкт № 4326 від 05.11.2020 року «Про внесення змін до Кодексу України про адміністративні правопорушення щодо проведення судово-психіатричної експертизи в адміністративному провадженні». Цим законопроектом пропонується внести зміни до ст. ст. 20, 38, 221, 268, 273, 277 КУПАП та доповнити КУпАП новою ст. 280-1 «Призначення судово-психіатричної експертизи», яка буде передбачати, що у разі наявності достатніх даних про те, що особа, яка притягується до адміністративної відповідальності, могла перебувати у стані неосудності під час вчинення протиправної дії чи бездіяльності:

орган (посадова особа), у провадженні якого перебуває справа про адміністративне правопорушення, призначає судово-психіатричну експертизу за згодою або клопотанням особи, яка притягується до адміністративної відповідальності, або іiї законного представника. 
У разі ненадання такої згоди протокол про адміністративне правопорушення разом з матеріалами справи для подальшого розгляду та прийняття рішення невідкладно, але не пізніше 24 годин, надсилається органом (посадовою особою) до суду;

- суд (суддя), у провадженні якого перебуває справа про адміністративне правопорушення, призначає судово-психіатричну експертизу за клопотанням особи, яка притягується до адміністративної відповідальності, або ії законного представника чи на власний розсуд.

Вирішення питання щодо необхідності проведення судово-психіатричної експертизи здійснюється за обов'язковою участю захисника.

У разі коли особа, яка притягується до адміністративної відповідальності, щодо якої вирішується питання про проведення судовопсихіатричної експертизи, не залучила захисника, орган (посадова особа), суд (суддя), у провадженні якого перебуває справа про адміністративне правопорушення, залучає його через орган (установу), уповноважений законом на надання безоплатної правової допомоги. Рішення органу (посадової особи), суду (судді), у провадженні якого перебуває справа про адміністративне правопорушення, про залучення захисника негайно направляється відповідному органу (установі), уповноваженому законом на надання безоплатної правової допомоги, для виконання.

Достатніми даними відповідно до примітки слід вважати видані закладами 3 надання психіатричної допомоги або лікарями-психіатрами документи, які підтверджують відомості про надання особі, яка притягується до адміністративної відповідальності, психіатричної допомоги та/або поведінку особи під час або після вчинення протиправної дії чи бездіяльності, яка була або $є$ неадекватною (затьмарення свідомості, порушення сприйняття, мислення, волі, емоцій, інтелекту чи пам'яті тощо) [2].»

У зв'язку з цим призначення судово-психіатричної експертизи без згоди особи, яка притягається до адміністративної відповідальності, можливе лише за рішенням суду, яке грунтується на підставі достатніх даних, але невизначеною залишається сама процедура та порядок отримання достатніх даних. Окрім визначених у проєкті Закону можуть бути й інші дані, які ставлять під сумнів осудність особи, що притягується до адміністративної відповідальності. До прикладу це можуть бути дані про неадекватну поведінку особи до моменту вчинення адміністративного правопорушення, або ж перебування на обліку у лікаря нарколога 3 приводу вживання алкоголю чи наркотичних речовин, що також може провокувати розлади ії психіки, але при цьому за допомогою до лікаря психіатра така особа могла ніколи не звертатися. 
Невизначеною також залишається сама процедура призначення судово-психіатричної експертизи, оскільки не передбачено яким документом може іiі призначити орган (посадова особа) у провадженні яких перебуває справа про адміністративне правопорушення, зокрема органами Національної поліцієї, які через прогалину у КУпАП на даний час $є$ позбавленими такої можливості. У судово-психіатричному відділенні Комунального некомерційного підприємства Львівської обласної ради «Львівська обласна клінічна психіатрична лікарня» за період 20172021 років проводилось декілька амбулаторних судово-психіатричних експертиз у справах про адміністративні правопорушення. Такі експертизи проводились або згідно Ухвали суду (як правило по епізодах ДТП), або згідно постанов органів дізнання прикордонних загонів (по справах незаконного перетину кордону) [3].

Підсумовуючи, можна зробити висновок, що оскільки перелік достатніх даних визначених приміткою до ст. 280-1 законопроєкту «Про внесення змін до Кодексу України про адміністративні правопорушення щодо проведення судово-психіатричної експертизи в адміністративному провадженні» не $\epsilon$ вичерпним, вважаємо за необхідне доповнити іiі словами: «, або інші дані про те, що особа, яка притягується до адміністративної відповідальності, могла перебувати у стані неосудності під час вчинення протиправної дії чи бездіяльності». Також пропонуємо чітко визначити форму документа для призначення судово-психіатричної експертизи, що дасть змогу іiі призначати органам Національної поліції як органові у провадження якого перебуває справа про адміністративне правопорушення.

\section{Література:}

1. Кодекс України про адміністративні правопорушення : Закон України від 07.12.1984 р. № 8073-X. URL:https://zakon.rada.gov.ua/laws/ show/80731-10\#Text (дата звернення 15.04.2021 року)

2. Проект Закону про внесення змін до Кодексу України про адміністративні правопорушення щодо проведення судово-психіатричної експертизи в адміністративному провадженні №4326 від 05.11.2020 URL:http://w1.c1.rada.gov.ua/pls/zweb2/webproc34?id=\&pf3511=70351\&pf $35401=537639$

3. Відповідь НКП ЛОР «Львівська обласна клінічна психіатрична лікарня» від 31.03.2021 №508/01.4.18 на 1 арк. 